\title{
The Ability of Edible Mushrooms to Act as Biocatalysts: Preparation of Chiral Alcohols Using Basidiomycete Strains
}

\author{
Kohji Ishihara $^{{ }^{*}}$, Yukiko Nishikawa1, Mari Kaneko ${ }^{1}$, Anna Kinoshita1, Nozomi Kumazawa1, \\ Daichi Kobashigawa ${ }^{1}$, Kohei Kuroda ${ }^{1}$, Masashi Osawa ${ }^{2}$, Tatsunori Yamamotoº \\ Nobuyoshi Nakajima ${ }^{3}$, Hiroki Hamada ${ }^{1}$, Noriyoshi Masuoka ${ }^{1}$ \\ ${ }^{1}$ Department of Life Science, Okayama University of Science, Okayama, Japan \\ ${ }^{2}$ Research Institute of Biotechnology, Fujiwara Techno-Art Co., Ltd., Okayama, Japan \\ ${ }^{3}$ Graduate School of Health and Welfare Science, Okayama Prefectiral University, Soja, Japan \\ Email: ${ }^{i}$ ishihara@dls.ous.ac.jp
}

Received January 16, 2012; revised March 12, 2012; accepted March 25, 2012

\begin{abstract}
To examine the potential ability of edible mushrooms to act as biocatalysts, 19 basidiomycete strains were screened. Modified media (PG, O, and PGO medium) for liquid cultivation of these basidiomycete strains were designed and tested. Wet cells ( $>10 \mathrm{~g}$ ) of 4 basidiomycete strains (Pleurotus salmoneostramineus H7, P. salmoneostramineus H13, Ganoderma lucidum NBRC31863, Flammulina velutipes NBRC31862) were harvested from PGO medium for 7 days. The stereoselective reduction of $\alpha$-keto esters using the 4 strains was tested. It was found that each of these strains had a reducing activity toward 6 aliphatic $\alpha$-keto esters. In the presence of L-alanine as an additive, the reduction of ethyl 2-oxobutanoate and ethyl 2-oxopentanoete by $P$. salmoneostramineus $\mathrm{H} 7$ produced the corresponding alcohol with a high conversion ratio and with excellent enantiomeric excess $(>99 \%$ e.e. $(R))$. Furthermore, ethyl pyruvate, ethyl 2oxobutanoate, and ethyl 2-oxopentanoate were predominantly reduced to the corresponding $(R)$-hydroxy ester ( $>99 \%$ e.e.) by G. lucidum. Thus, we found that these edible mushrooms have great potential to be used as biocatalysts for the stereoselective reduction of carbonyl compounds.
\end{abstract}

Keywords: Basidiomycete; Edible Mushroom; Biocatalyst; Chiral Alcohol

\section{Introduction}

A mushroom is the fleshy, spore-bearing fruiting body of a fungus, typically produced above ground on soil. The mushroom has been used as a food since ancient times, and more recently has again attracted attention as a functional food material. Edible mushrooms have been utilized as food and occasionally as medicines (medical mushrooms). The abilities of some mushrooms to inhibit tumor growth and to modulate the immune system have been studied [1-3]. Furthermore, the degradation of persistent organic substances and substances that are not readily degradable, such as DTT, dioxins, and PCBs, by use of certain mushrooms has been attempted and investigated [4-7]. Thus, the mushroom is one of the noteworthy microorganisms in food, medical, and environmental sciences; however, there are few reports about the applications of the mushrooms in other science fields.

In the $21^{\text {st }}$ century it became impossible to disregard

${ }^{*}$ Corresponding author. exhaustion of the earth's resources. Therefore, the effective use of resources is an important focus of research. In the interest of the effective use of resources and environmental protection, we investigated an environmentally friendly method of producing useful compounds, using microorganisms as the bio-resource. It has been demonstrated that microorganisms such as actinomycetes, micro green algae, and other bacteria are useful biocatalysts in the production of optically active alcohols (chiral building brocks) [8-14]. However, little information is known about the potential for edible mushrooms to act as biocatalysts for asymmetric organic syntheses.

This study describes the stereoselective reduction of $\alpha$-keto esters by edible mushrooms as novel biocatalysts (Figure 1).

\section{Material and Methods}

\subsection{Instruments and Chemicals}

Gas chromatography was done using GL Science GC353 gas chromatographs (DB-Wax, Agilent Technolo- 


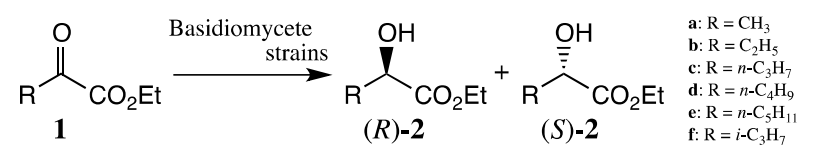

Figure 1. The reduction of $\alpha$-keto esters (1a-f) by basidiomycete strains.

gies, Santa Clara, CA, USA, $0.25 \mathrm{~mm} \times 30 \mathrm{~m}$; TC-1, GL Science, Tokyo, Japan, $0.25 \mathrm{~mm} \times 30 \mathrm{~m}$; CP-ChirasilDEX CB, Varian Inc., Lake Forest, CA, USA, $0.25 \mathrm{~mm}$ $\times 25$ m; Gamma DEX 225, Sigma-Aldrich Co., St. Louise, MO, USA, $0.25 \mathrm{~mm} \times 30 \mathrm{~m}$ ). Ethyl pyruvate (Figure 1, 1a), diatomaceous earth (granular), polypeptone, L-alanine, olive oil, pectin (from apple), and Daigo's potato dextrose agar (PDA) were purchased from Wako Pure Chemical Industries Ltd., Osaka, Japan. Difco ${ }^{\mathrm{TM}}$ potato dextrose broth (PDB) and Bacto ${ }^{\mathrm{TM}}$ yeast extract were purchased from Becton, Dickinson and Co., Franklin Lakes, NJ, USA. Arabic gum and ethyl 3-methyl-2-oxobutanoate (1f) were purchased from Sigma-Aldrich. Ethyl 2-oxobutanoate (1b), ethyl 2-oxopentanoate (1c), ethyl 2oxohexanoate (1d), ethyl 2-oxoheptanoate (1e), and $\alpha$ hydroxy esters (2a-f) were prepared according to the procedures in the literature [15]. All other chemicals used in this study were of analytical grade and comercially available.

\subsection{Microorganisms and Cultivation}

The Pleurotus salmoneostramineus H7 (Japanese name: tokiiro-hiratake), P. salmoneostramineus $\mathrm{H} 13$, and Lepista sordida (Japanese name: komurasaki-shimeji) were purchased from the Research Institute of Biotechnology, Fujiwara Techno-Art Co., Ltd., Japan. Agaricus bisporus NBRC30774, Agaricus bisporus NBRC30782, Flammulina velutipes NBRC31862 (Japanese name: enoki-take), Ganoderma lucidum NBRC31863 (Japanese name: mannen-take), Grifola frondosa NBRC30552 (Japanese name: mai-take), Grifola frondosa NBRC30661, Grifola frondosa NBRC32987, Hericium erinaceum NBRC-100328 (Japanese name: yamabushi-take), Lentinula edodes NBRC30719, Lentinula edodes NBRC30720 (Japanese name: shii-take), Lentinula edodes NBRC-30723, Lentinula edodes NBRC30724, Lyophyllum ulmarium NBRC30775 (Japanese name: buna-shimeji), Pholiota nameko NBRC30372 (Japanese name: nameko), Tricholoma matsutake NBRC30773 (Japanese name: matsu-take), and Tricholoma giganteum NBRC31860 (Japanese name: niou-shimeji) were purchased from the National Institute of Technology and Evaluation, Biological Resource Center, Japan (NBRC). These basidiomycete strains were maintained at $25^{\circ} \mathrm{C}$ in PDA. The basidiomycete strains were grown in PDB and synthetic media (PG, O, or PGO medium) $(200 \mathrm{~mL})$ for $6-30$ days at $25^{\circ} \mathrm{C}$ with aerobic rotary shaking at $95 \mathrm{~min}^{-1}$ in a baffled $500-\mathrm{mL}$ flask in the dark. The $\mathrm{PG}$ medium comprised $20 \mathrm{~g}$ glucose, $4 \mathrm{~g}$ polypepton, $1 \mathrm{~g} \mathrm{Bacto}{ }^{\mathrm{TM}}$ yeast extract, $0.46 \mathrm{~g} \mathrm{KH}_{2} \mathrm{PO}_{4}, 1 \mathrm{~g}$ $\mathrm{K}_{2} \mathrm{HPO}_{4}, 2 \mathrm{~g}$ pectin, and $2 \mathrm{~g}$ arabic gum per 1 liter of distilled water ( $\mathrm{pH}$ 5.5). The $\mathrm{O}$ medium comprised $20 \mathrm{~g}$ glucose, $4 \mathrm{~g}$ polypepton, $1 \mathrm{~g}$ Bacto $^{\mathrm{TM}}$ yeast extract, $0.46 \mathrm{~g}$ $\mathrm{KH}_{2} \mathrm{PO}_{4}, 1 \mathrm{~g} \mathrm{~K}_{2} \mathrm{HPO}_{4}$, and $10 \mathrm{~g}$ olive oil per 1 liter of distilled water ( $\mathrm{pH}$ 5.5). The PGO medium comprised 20 g glucose, $4 \mathrm{~g}$ polypepton, $1 \mathrm{~g}$ Bacto ${ }^{\mathrm{TM}}$ yeast extract, 0.46 $\mathrm{g} \mathrm{KH}_{2} \mathrm{PO}_{4}, 1 \mathrm{~g} \mathrm{~K}_{2} \mathrm{HPO}_{4}, 2$ g pectin, $2 \mathrm{~g}$ arabic gum, and $10 \mathrm{~g}$ olive oil per 1 liter of distilled water ( $\mathrm{pH} 5.5)$. The basidiomycete cells were harvested by filtration on a filter paper in vacuo and washed with saline $(0.85 \%$ aqueous $\mathrm{NaCl}$ ).

\subsection{Reduction of $\alpha$-Keto Esters with Basidiomycete Whole Cells}

The saline-washed wet cells $(0.5 \mathrm{~g})$ were resuspended in a large test tube $(\phi 30 \mathrm{~mm} \times 200 \mathrm{~mm})$ containing $20 \mathrm{~mL}$ of saline (or water), the substrate $(0.15 \mathrm{mmol}$; corresponding substrate concentration was $7.5 \mathrm{mM})$ and additive $(5.0 \mathrm{mmol})$ were added, and the culture was incubated aerobically (reciprocating shaking at $120 \mathrm{~min}^{-1}$ ) at $25^{\circ} \mathrm{C}$. A portion of the reaction mixture was filtered using a diatomaceous earth short column $(\phi 10 \mathrm{~mm} \times 30$ $\mathrm{mm}$ ), extracted with diethyl ether, and then concentrated under reduced pressure.

\subsection{Analysis}

Conversions of produced alcohols (Figure 1, 2a-f) were measured using a GLC with a DB-WAX capillary column $\left(100 \mathrm{kPa} \mathrm{He}, 110^{\circ} \mathrm{C}\right.$; 1a, $3.78 \mathrm{~min} ; \mathbf{2 a}, 4.75 \mathrm{~min} ; \mathbf{1 b}$, $4.73 \mathrm{~min}$; $\mathbf{2 b}, 5.92 \mathrm{~min} ; \mathbf{1 f}, 4.54 \mathrm{~min} ; \mathbf{2 f}, 6.41 \mathrm{~min} ; 120^{\circ} \mathrm{C}$; 1c, $4.84 \mathrm{~min} ; 2$ 2c, $6.45 \mathrm{~min} ; 150^{\circ} \mathrm{C}$, 1d, $3.83 \mathrm{~min}$; $2 \mathrm{~d}, 4.68$ $\mathrm{min} ; \mathbf{1 e}, 4.78 \mathrm{~min} ; \mathbf{2 e}, 6.07 \mathrm{~min})$. The enantiomeric excesses (e.e.) of the products were measured using a GLC equipped with an optically active CP-Chirasil-DEX CB (2a-e) or Gamma DEX 225 capillary column (2f). The e.e. was calculated by the following formula; e.e. $(\%)=$ $\{(R-S) /(R+S)\} \times 100$. These $R$ and $S$ are the respective peak areas on GLC analyses. The absolute configurations of $\alpha$-hydroxy esters (2a-f) were identified by comparing their retention times from the GLC analyses with those of authentic samples [15].

\section{Results and Discussion}

\subsection{Screening of Basidiomycete Strains and Cultivation Media}

The recommended medium for most basidiomycete strains tested in this study was PDA. However, all strains cultivated in PDB, with the exception of Flammulina velutipes, Ganoderma lucidum, and Pleurotus salmoneostramineus, resulted in $2 \mathrm{~g}$ or less of wet cells, even if 
cultured for over 1 month in PDB (Table 1). To improve the cultivation rate in PDB, 3 new culture media (PG, O, and PGO medium) containing pectin, arabic gum, and olive oil were designed and tested for efficacy. We found that the cultivation in the PGO medium produced more wet cells than cultivation in other media (PDB, PG, and $\mathrm{O}$ medium) in a short time. Although cultivation of basidiomycete strains in the liquid medium requires a longer time compared to yeast strains and actinomycetes,

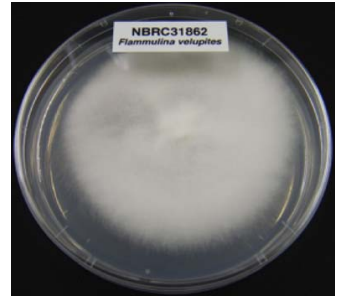

Flammulina velutipes NBRC31862

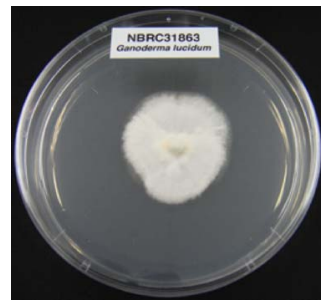

Ganoderma lucidum NBRC31863

the efficient cultivation of basidiomycetes was attained in the PGO medium we designed. In particular, over $10 \mathrm{~g}$ of wet cells from 4 basidiomycete strains ( $F$. velutipes NBRC31862, G. lucidum NBRC31863, P. salmoneostramineus $\mathrm{H} 7$, and $P$. salmoneostramineus $\mathrm{H} 13)$ were harvested after cultivation in PGO medium for 1 week. Therefore, we investigated the possibility that these 4 strains (see Figure 2) can act as biocatalysts for the asymmetric reduction of carbonyl compounds.

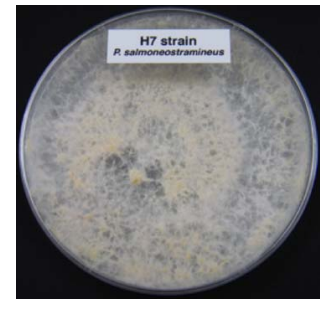

P. salmoneostramineus $\mathrm{H} 7$

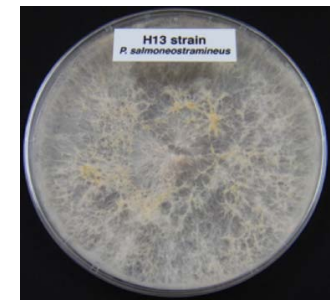

P. salmoneostramineus H13

Figure 2. Pictures of basidiomycete strains used for the reduction of keto esters.

Table 1. The cultivation of basidiomycete strains in various culture media ${ }^{1}$.

\begin{tabular}{|c|c|c|c|c|c|c|c|c|c|}
\hline \multirow{2}{*}{ Strains } & & \multicolumn{2}{|c|}{ PDB } & \multicolumn{2}{|c|}{ PG medium ${ }^{2}$} & \multicolumn{2}{|c|}{$\mathrm{O}_{\text {medium }}^{2}$} & \multicolumn{2}{|c|}{ PGO medium ${ }^{2}$} \\
\hline & & wet cells $(\mathrm{g})$ & time (day) & wet cells (g) & time (day) & wet cells (g) & time (day) & wet cells $(\mathrm{g})$ & time (day) \\
\hline Pholita nameko & NBRC30372 & 0.5 & 30 & 7.0 & 17 & 7.0 & 14 & 6.0 & 10 \\
\hline Grifola frondosa & NBRC30552 & 1.0 & 30 & 1.2 & 18 & 1.2 & 16 & 2.0 & 10 \\
\hline Grifola frondosa & NBRC30661 & 0.5 & 25 & 0.7 & 14 & 0.6 & 12 & 1.0 & 10 \\
\hline Lentinula edodes & NBRC30719 & 1.5 & 30 & 1.0 & 14 & 1.2 & 12 & 2.0 & 10 \\
\hline Lentinula edodes & NBRC30720 & 1.0 & 30 & 1.0 & 14 & 0.8 & 12 & 1.0 & 10 \\
\hline Lentinula edodes & NBRC30723 & 0.5 & 30 & 0.8 & 14 & 1.0 & 1 & 1.5 & 10 \\
\hline Lentinula edodes & NBRC30724 & 1.0 & 30 & 1.1 & 14 & 1.3 & 12 & 2.5 & 10 \\
\hline Tricholoma matsutake & NBRC30773 & 0.1 & 30 & 0.1 & 30 & 0.1 & 30 & 0.1 & 20 \\
\hline Agaricus bisporus & NBRC30774 & 0.5 & 30 & 0.8 & 14 & 1.5 & 14 & 2.0 & 14 \\
\hline Lyophyllum ulmarium & NBRC30775 & 0.5 & 30 & 3.0 & 11 & 7.0 & 15 & 7.0 & 10 \\
\hline Agaricus bisporus & NBRC30782 & 0.5 & 20 & 1.0 & 14 & 1.5 & 14 & 1.8 & 14 \\
\hline Tricholoma giganteum & NBRC31680 & 1.2 & 15 & 1.0 & 12 & 1.8 & 14 & 2.0 & 10 \\
\hline Flammulina velutipes & NBRC31862 & 7.0 & 15 & 7.0 & 10 & 8.0 & 15 & 10.0 & 7 \\
\hline Ganoderma lucidum & NBRC31683 & 8.0 & 15 & 6.0 & 12 & 4.0 & 9 & 10.5 & 7 \\
\hline Grifola frondosa & NBRC32987 & 0.5 & 30 & 0.5 & 14 & 1.3 & 12 & 2.1 & 14 \\
\hline Hericium erinaceum & NBRC100328 & 2.5 & 30 & 1.5 & 14 & 1.5 & 12 & 2.0 & 10 \\
\hline $\begin{array}{l}\text { Pleurotus } \\
\quad \text { salmoneostramineus }\end{array}$ & $\mathrm{H} 7$ & 18.0 & 15 & 13.5 & 12 & 12.0 & 10 & 15.0 & 7 \\
\hline $\begin{array}{l}\text { Pleurotus } \\
\quad \text { salmoneostramineus }\end{array}$ & $\mathrm{H} 13$ & 20.0 & 15 & 15.0 & 12 & 11.0 & 10 & 14.0 & 7 \\
\hline Lepista sordida & & 0.5 & 32 & 0.5 & 30 & 1.0 & 20 & 1.5 & 14 \\
\hline
\end{tabular}

${ }^{1}$ The basidiomycete strains were grown in the medium at $25^{\circ} \mathrm{C}$ with aerobic rotary shaking $\left(110 \mathrm{~min}^{-1}\right)$ in baffled 500 -mL flask in the dark condition; ${ }^{2} \mathrm{Com}-$ position of each culture medium was described in materials and method section. 


\subsection{Ability to Reduce $\alpha$-Keto Esters}

Four basidiomycete strains were tested for their ability to reduce $\alpha$-keto esters (Figure 1). The results of the $\alpha$-keto ester reductions (1a-f) are summarized in Tables 2-5. The reduction of substrates by the $P$. salmoneostramineus $\mathrm{H} 7$ strain cultivated in the PGO medium exhibited a higher conversion ratio compared to reduction by the same strain cultivated in the PDB medium (Table 2). Furthermore, when the concentration of the reaction solvent, saline, was diluted from $0.85 \%$ to $0.085 \%$, the time to reach the maximum conversion was shortened, while the stereoselectivity of the produced hydroxy esters decreased. An additive was introduced into the reaction mixture to improve the stereoselectivity. As a result, the reduction of ethyl 2-oxobutanoate (1b), ethyl 2-oxopentanoate (1c), and ethyl 2-oxoheptanoate (1e) in the presence of L-alanine produced the corresponding alcohols in excellent e.e. (2b, $>99 \%$ e.e. $(R) ; \mathbf{2 c},>99 \%$ e.e. $(R) ; \mathbf{2 e}$, $>99 \%$ e.e. $(S)$, respectively). The effects of other additives (L-glycine, L-glutamate, L-aspartate, ascorbate, $\mathrm{CaCl}_{2}, \mathrm{MnCl}_{2}$, allyl alcohol, methyl vinyl ketone, quercetin, etc.) were tested; however, the stereoselectivity of the produced alcohols did not increase (data not shown).

As shown in Table 3, the reduction of substrates by the PGO-cultivated $P$. salmoneostramineus $\mathrm{H} 13$ strain was faster (2a-d, conversion $>99 \%$ after $24 \mathrm{~h}$ ) compared with that of the PDB-cultivated H13 strain. However, improvement in the enantioselectivity of the hydroxy

Table 2. The reduction of $\alpha$-keto esters (1a-f) to the corresponding $\alpha$-hydroxy esters (2a-f) by P. salmoneostramineus H7.

\begin{tabular}{|c|c|c|c|c|c|c|c|c|c|c|c|c|c|c|c|c|}
\hline \multirow{2}{*}{ Product } & \multicolumn{4}{|c|}{$\mathrm{PDB} / 0.85 \% \mathrm{NaCl}^{1}$} & \multicolumn{4}{|c|}{$\mathrm{PGO} / 0.85 \% \mathrm{NaCl}^{2}$} & \multicolumn{4}{|c|}{$\mathrm{PGO} / 0.085 \% \mathrm{NaCl}^{3}$} & \multicolumn{4}{|c|}{$\mathrm{PGO} / 0.85 \% \mathrm{NaCl} / \mathrm{L}-\mathrm{Ala}^{4}$} \\
\hline & $\begin{array}{l}\text { conv. } \\
(\%)^{5}\end{array}$ & $\begin{array}{l}\text { e.e. } \\
(\%)^{6}\end{array}$ & $(R / S)^{6}$ & $\begin{array}{l}\text { time } \\
\text { (h) }\end{array}$ & $\begin{array}{l}\text { conv. } \\
(\%)^{5}\end{array}$ & $\begin{array}{l}\text { e.e. } \\
(\%)^{6}\end{array}$ & $(R / S)^{6}$ & time (h) & $\begin{array}{l}\text { conv. } \\
(\%)^{5}\end{array}$ & $\begin{array}{l}\text { e.e. } \\
(\%)^{6}\end{array}$ & $(R / S)^{6}$ & $\begin{array}{l}\text { time } \\
\text { (h) }\end{array}$ & $\begin{array}{l}\text { conv. } \\
(\%)^{5}\end{array}$ & $\begin{array}{l}\text { e.e. } \\
(\%)^{6}\end{array}$ & $(R / S)^{6}$ & $\begin{array}{l}\text { time } \\
\text { (h) }\end{array}$ \\
\hline $2 a$ & $>99$ & 78 & $S$ & 48 & $>99$ & 85 & $S$ & 48 & $>99$ & 88 & $S$ & 12 & $>99$ & 92 & $S$ & 24 \\
\hline $2 \mathbf{b}$ & 85 & 76 & $S$ & 48 & $>99$ & 53 & $S$ & 48 & $>99$ & 44 & $S$ & 24 & $>99$ & $>99$ & $R$ & 24 \\
\hline 2c & $>99$ & 68 & $S$ & 24 & $>99$ & 60 & $S$ & 24 & $>99$ & 42 & $S$ & 12 & $>99$ & $>99$ & $R$ & 24 \\
\hline 2d & 98 & 94 & $S$ & 48 & $>99$ & 92 & $S$ & 48 & $>99$ & 77 & $S$ & 12 & $>99$ & 76 & $R$ & 24 \\
\hline $2 e$ & 42 & $>99$ & $S$ & 48 & 38 & $>99$ & $S$ & 48 & 56 & 77 & $S$ & 24 & 86 & $>99$ & $S$ & 24 \\
\hline $2 f$ & $>99$ & 85 & $S$ & 24 & $>99$ & 67 & $S$ & 24 & $>99$ & 43 & $S$ & 12 & $>99$ & 86 & $S$ & 24 \\
\hline
\end{tabular}

${ }^{1}$ Substrate $(0.15 \mathrm{mmol})$ and $0.85 \% \mathrm{NaCl}$ aq. $(20 \mathrm{ml})$ were added to the wet cells $(0.5 \mathrm{~g})$ cultivated in PDB, and the reaction mixture was incubated aerobically (reciprocating shaking at $\left.120 \mathrm{~min}^{-1}\right)$ at $25^{\circ} \mathrm{C} ;{ }^{2}$ Substrate $(0.15 \mathrm{mmol})$ and $0.85 \% \mathrm{NaCl}$ aq. $(20 \mathrm{ml})$ were added to the wet cells $(0.5 \mathrm{~g})$ cultivated in PGO-medium, and the reaction mixture was incubated aerobically (reciprocating shaking at $120 \mathrm{~min}^{-1}$ ) at $25^{\circ} \mathrm{C}$; ${ }^{3}$ Substrate $(0.15 \mathrm{mmol})$ and $0.085 \% \mathrm{NaCl}$ aq. $(20 \mathrm{ml})$ were added to the wet cells $(0.5 \mathrm{~g})$ cultivated in PGO-medium, and the reaction mixture was incubated aerobically (reciprocating shaking at 120 min $\left.{ }^{-1}\right)$ at $25^{\circ} \mathrm{C}$; ${ }^{4}$ Substrate $(0.15 \mathrm{mmol})$, L-alanine $(5.0 \mathrm{mmol})$, and $0.085 \% \mathrm{NaCl}$ aq. $(20 \mathrm{ml})$ were added to the wet cells $(0.5 \mathrm{~g})$ cultivated in PGO-medium, and the reaction mixture was incubated aerobically (reciprocating shaking at $120 \mathrm{~min}^{-1}$ ) at $25^{\circ} \mathrm{C} ;{ }^{5}$ Conversion was measured by a GLC analysis; ${ }^{6}$ Enantiomeric excess (e.e.) and configuration $(R / S)$ were determined by GLC analyses with optically active capillary columns.

Table 3. The reduction of $\alpha$-keto esters (1a-f) to the corresponding $\alpha$-hydroxy esters (2a-f) by P. salmoneostramineus H13.

\begin{tabular}{|c|c|c|c|c|c|c|c|c|c|c|c|c|c|c|c|c|}
\hline \multirow{2}{*}{ Product } & \multicolumn{4}{|c|}{$\mathrm{PDB} / 0.85 \% \mathrm{NaCl}^{1}$} & \multicolumn{4}{|c|}{$\mathrm{PGO} / 0.85 \% \mathrm{NaCl}^{2}$} & \multicolumn{4}{|c|}{$\mathrm{PGO} / 0.085 \% \mathrm{NaCl}^{3}$} & \multicolumn{4}{|c|}{$\mathrm{PGO} / 0.85 \% \mathrm{NaCl} / \mathrm{L}-\mathrm{Ala}^{4}$} \\
\hline & $\begin{array}{l}\text { conv. } \\
(\%)^{5}\end{array}$ & $\begin{array}{l}\text { e.e. } \\
(\%)^{6}\end{array}$ & $(R / S)^{6}$ & $\begin{array}{l}\text { time } \\
\text { (h) }\end{array}$ & $\begin{array}{l}\text { conv. } \\
(\%)^{5}\end{array}$ & $\begin{array}{l}\text { e.e. } \\
(\%)^{6}\end{array}$ & $(R / S)^{6}$ & $\begin{array}{l}\text { time } \\
\text { (h) }\end{array}$ & $\begin{array}{l}\text { conv. } \\
(\%)^{5}\end{array}$ & $\begin{array}{l}\text { e.e. } \\
(\%)^{6}\end{array}$ & $(R / S)^{6}$ & $\begin{array}{l}\text { time } \\
\text { (h) }\end{array}$ & $\begin{array}{l}\text { conv. } \\
(\%)^{5}\end{array}$ & $\begin{array}{l}\text { e.e. } \\
(\%)^{6}\end{array}$ & $(R / S)^{6}$ & $\begin{array}{l}\text { time } \\
\text { (h) }\end{array}$ \\
\hline $2 a$ & $>99$ & 83 & $S$ & 48 & $>99$ & 79 & $S$ & 48 & $>99$ & 87 & $S$ & 12 & $>99$ & 80 & $S$ & 24 \\
\hline $2 \mathbf{b}$ & $>99$ & 59 & $S$ & 48 & $>99$ & 65 & $S$ & 48 & $>99$ & 66 & $S$ & 24 & $>99$ & $>99$ & $R$ & 24 \\
\hline 2c & $>99$ & 49 & $S$ & 24 & $>99$ & 76 & $S$ & 24 & $>99$ & $>99$ & $R$ & 24 & 96 & 86 & $S$ & 24 \\
\hline 2d & 98 & 86 & $S$ & 48 & $>99$ & 96 & $S$ & 24 & $>99$ & 69 & $S$ & 12 & 98 & 82 & $R$ & 24 \\
\hline $2 e$ & 46 & 76 & $S$ & 48 & 94 & $>99$ & $R$ & 24 & 88 & 81 & $S$ & 12 & 99 & 75 & $S$ & 24 \\
\hline $2 f$ & $>99$ & 84 & $S$ & 24 & $>99$ & 84 & $S$ & 48 & $>99$ & 33 & $S$ & 12 & $>99$ & 27 & $S$ & 24 \\
\hline
\end{tabular}

${ }^{1}$ Substrate $(0.15 \mathrm{mmol})$ and $0.85 \% \mathrm{NaCl}$ aq. $(20 \mathrm{ml})$ were added to the wet cells $(0.5 \mathrm{~g})$ cultivated in PDB, and the reaction mixture was incubated aerobically (reciprocating shaking at $\left.120 \mathrm{~min}^{-1}\right)$ at $25^{\circ} \mathrm{C} ;{ }^{2}$ Substrate $(0.15 \mathrm{mmol})$ and $0.85 \% \mathrm{NaCl}$ aq. $(20 \mathrm{ml})$ were added to the wet cells $(0.5 \mathrm{~g})$ cultivated in PGO-medium, and the reaction mixture was incubated aerobically (reciprocating shaking at $120 \mathrm{~min}^{-1}$ ) at $25^{\circ} \mathrm{C} ;{ }^{3}$ Substrate $(0.15 \mathrm{mmol})$ and $0.085 \% \mathrm{NaCl}$ aq. $(20 \mathrm{ml}) \mathrm{were}$ added to the wet cells $(0.5 \mathrm{~g})$ cultivated in PGO-medium, and the reaction mixture was incubated aerobically (reciprocating shaking at 120 min $\left.{ }^{-1}\right)$ at $25^{\circ} \mathrm{C}$; ${ }^{4}$ Substrate $(0.15 \mathrm{mmol})$, L-alanine $(5.0 \mathrm{mmol})$, and $0.085 \% \mathrm{NaCl}$ aq. $(20 \mathrm{ml})$ were added to the wet cells $(0.5 \mathrm{~g})$ cultivated in PGO-medium, and the reaction mixture was incubated aerobically (reciprocating shaking at $120 \mathrm{~min}^{-1}$ ) at $25^{\circ} \mathrm{C} ;{ }^{5}$ Conversion was measured by a GLC analysis; ${ }^{6}$ Enantiomeric excess (e.e.) and configuration $(R / S)$ were determined by GLC analyses with optically active capillary columns. 
Table 4. The reduction of $\alpha$-keto esters (1a-f) to the corresponding $\alpha$-hydroxy esters (2a-f) by Ganoderma lucidum NBRC31863.

\begin{tabular}{|c|c|c|c|c|c|c|c|c|c|c|c|c|c|c|c|c|}
\hline \multirow{2}{*}{ Product } & \multicolumn{4}{|c|}{$\mathrm{PDB} / 0.85 \% \mathrm{NaCl}^{1}$} & \multicolumn{4}{|c|}{$\mathrm{PGO} / 0.85 \% \mathrm{NaCl}^{2}$} & \multicolumn{4}{|c|}{$\mathrm{PGO} / 0.085 \% \mathrm{NaCl}^{3}$} & \multicolumn{4}{|c|}{$\mathrm{PGO} / 0.85 \% \mathrm{NaCl} / \mathrm{L}-\mathrm{Ala}^{4}$} \\
\hline & $\begin{array}{l}\text { conv. } \\
(\%)^{5}\end{array}$ & $\begin{array}{l}\text { e.e. } \\
(\%)^{6}\end{array}$ & $(R / S)^{6}$ & $\begin{array}{l}\text { time } \\
\text { (h) }\end{array}$ & $\begin{array}{l}\text { conv. } \\
(\%)^{5}\end{array}$ & $\begin{array}{l}\text { e.e. } \\
(\%)^{6}\end{array}$ & $(R / S)^{6}$ & $\begin{array}{l}\text { time } \\
\text { (h) }\end{array}$ & $\begin{array}{l}\text { conv. } \\
(\%)^{5}\end{array}$ & $\begin{array}{l}\text { e.e. } \\
(\%)^{6}\end{array}$ & $(R / S)^{6}$ & $\begin{array}{l}\text { time } \\
\text { (h) }\end{array}$ & $\begin{array}{l}\text { conv. } \\
(\%)^{5}\end{array}$ & $\begin{array}{l}\text { e.e. } \\
(\%)^{6}\end{array}$ & $(R / S)^{6}$ & $\begin{array}{l}\text { time } \\
\text { (h) }\end{array}$ \\
\hline $2 a$ & 60 & 54 & $S$ & 48 & $>99$ & 54 & $S$ & 48 & $>99$ & 29 & $S$ & 12 & $>99$ & $>99$ & $R$ & 24 \\
\hline $2 \mathbf{b}$ & 47 & 28 & $S$ & 48 & $>99$ & 85 & $R$ & 48 & $>99$ & 96 & $R$ & 12 & $>99$ & $>99$ & $R$ & 24 \\
\hline 2c & 75 & 50 & $S$ & 48 & $>99$ & 58 & $S$ & 48 & $>99$ & 17 & $S$ & 12 & $>99$ & $>99$ & $R$ & 24 \\
\hline 2d & 51 & 62 & $S$ & 24 & $>99$ & 86 & $R$ & 48 & $>99$ & 64 & $S$ & 12 & $>99$ & 69 & $R$ & 12 \\
\hline $2 e$ & 26 & 67 & $S$ & 48 & 27 & 50 & $S$ & 24 & 24 & 64 & $S$ & 12 & $>99$ & 56 & $R$ & 24 \\
\hline $2 f$ & 33 & 59 & $S$ & 48 & 60 & 24 & $S$ & 48 & $>99$ & 65 & $R$ & 48 & $>99$ & 56 & $R$ & 6 \\
\hline
\end{tabular}

${ }^{1}$ Substrate $(0.15 \mathrm{mmol})$ and $0.85 \% \mathrm{NaCl}$ aq. $(20 \mathrm{ml})$ were added to the wet cells $(0.5 \mathrm{~g})$ cultivated in PDB, and the reaction mixture was incubated aerobically (reciprocating shaking at $\left.120 \mathrm{~min}^{-1}\right)$ at $25^{\circ} \mathrm{C} ;{ }^{2}$ Substrate $(0.15 \mathrm{mmol})$ and $0.85 \% \mathrm{NaCl}$ aq. $(20 \mathrm{ml})$ were added to the wet cells $(0.5 \mathrm{~g})$ cultivated in PGO-medium, and the reaction mixture was incubated aerobically (reciprocating shaking at $\left.120 \mathrm{~min}^{-1}\right)$ at $25^{\circ} \mathrm{C} ;{ }^{3}$ Substrate $(0.15 \mathrm{mmol})$ and water $(20 \mathrm{ml})$ were added to the wet cells $(0.5 \mathrm{~g})$ cultivated in PGO-medium, and the reaction mixture was incubated aerobically (reciprocating shaking at 120 min $\left.^{-1}\right)$ at $25^{\circ} \mathrm{C} ;{ }^{4} \mathrm{Substrate}(0.15$ $\mathrm{mmol})$, L-alanine $(5.0 \mathrm{mmol})$, and water $(20 \mathrm{ml})$ were added to the wet cells $(0.5 \mathrm{~g})$ cultivated in PGO-medium, and the reaction mixture was incubated aerobically (reciprocating shaking at $120 \mathrm{~min}^{-1}$ ) at $25^{\circ} \mathrm{C} ;{ }^{5}$ Conversion was measured by a GLC analysis; ${ }^{6}$ Enantiomeric excess (e.e.) and configuration $(R / S)$ were determined by GLC analyses with optically active capillary columns.

Table 5. The reduction of $\alpha$-keto esters (1a-f) to the corresponding $\alpha$-hydroxy esters (2a-f) by Flammulina velutipes NBRC31862.

\begin{tabular}{|c|c|c|c|c|c|c|c|c|c|c|c|c|c|c|c|c|}
\hline \multirow[b]{2}{*}{ Product } & \multicolumn{4}{|c|}{$\mathrm{PDB} / 0.85 \% \mathrm{NaCl}^{1}$} & \multicolumn{4}{|c|}{$\mathrm{PGO} / 0.85 \% \mathrm{NaCl}^{2}$} & \multicolumn{4}{|c|}{$\mathrm{PGO} / 0.085 \% \mathrm{NaCl}^{3}$} & \multicolumn{4}{|c|}{$\mathrm{PGO} / 0.85 \% \mathrm{NaCl} / \mathrm{L}-\mathrm{Ala}^{4}$} \\
\hline & $\begin{array}{l}\text { conv. } \\
(\%)^{5}\end{array}$ & $\begin{array}{l}\text { e.e. } \\
(\%)^{6}\end{array}$ & $(R / S)^{6}$ & $\begin{array}{l}\text { time } \\
\text { (h) }\end{array}$ & $\begin{array}{l}\text { conv. } \\
(\%)^{5}\end{array}$ & $\begin{array}{l}\text { e.e. } \\
(\%)^{6}\end{array}$ & $(R / S)^{6}$ & $\begin{array}{l}\text { time } \\
\text { (h) }\end{array}$ & $\begin{array}{l}\text { conv. } \\
(\%)^{5}\end{array}$ & $\begin{array}{l}\text { e.e. } \\
(\%)^{6}\end{array}$ & $(R / S)^{6}$ & $\begin{array}{l}\text { time } \\
\text { (h) }\end{array}$ & $\begin{array}{l}\text { conv. } \\
(\%)^{5}\end{array}$ & $\begin{array}{l}\text { e.e. } \\
(\%)^{6}\end{array}$ & $(R / S)^{6}$ & $\begin{array}{l}\text { time } \\
\text { (h) }\end{array}$ \\
\hline $2 a$ & $>99$ & 66 & $S$ & 48 & $>99$ & 71 & $S$ & 24 & $>99$ & 75 & $S$ & 24 & $>99$ & 71 & $S$ & 24 \\
\hline $2 \mathbf{b}$ & $>99$ & 14 & $S$ & 48 & 92 & $>99$ & $R$ & 48 & $>99$ & 20 & $S$ & 12 & $>99$ & 26 & $S$ & 12 \\
\hline 2c & $>99$ & 3 & $R$ & 48 & $>99$ & 22 & $R$ & 48 & $>99$ & 32 & $R$ & 48 & $>99$ & 44 & $R$ & 48 \\
\hline 2d & $>99$ & 2 & $R$ & 48 & 86 & 8 & $R$ & 48 & $>99$ & 13 & $R$ & 24 & $>99$ & 25 & $R$ & 24 \\
\hline $2 e$ & $>99$ & 37 & $S$ & 48 & 75 & 34 & $S$ & 24 & 98 & 17 & $S$ & 12 & 98 & 12 & $S$ & 12 \\
\hline $2 f$ & $>99$ & 9 & $R$ & 48 & 84 & 8 & $R$ & 48 & $>99$ & 31 & $R$ & 24 & $>99$ & 85 & $R$ & 24 \\
\hline
\end{tabular}

${ }^{1}$ Substrate $(0.15 \mathrm{mmol})$ and $0.85 \% \mathrm{NaCl}$ aq. $(20 \mathrm{ml})$ were added to the wet cells $(0.5 \mathrm{~g})$ cultivated in PDB, and the reaction mixture was incubated aerobically (reciprocating shaking at $\left.120 \mathrm{~min}^{-1}\right)$ at $25^{\circ} \mathrm{C}$; ${ }^{2}$ Substrate $(0.15 \mathrm{mmol})$ and $0.85 \% \mathrm{NaCl}$ aq. $(20 \mathrm{ml})$ were added to the wet cells $(0.5 \mathrm{~g})$ cultivated in PGO-medium, and the reaction mixture was incubated aerobically (reciprocating shaking at $\left.120 \mathrm{~min}^{-1}\right)$ at $25^{\circ} \mathrm{C}$; ${ }^{3}$ Substrate $(0.15 \mathrm{mmol})$ and water $(20 \mathrm{ml})$ were added to the wet cells $(0.5 \mathrm{~g})$ cultivated in PGO-medium, and the reaction mixture was incubated aerobically (reciprocating shaking at 120 min $\left.{ }^{-1}\right)$ at $25^{\circ} \mathrm{C} ;{ }^{4}$ Substrate $(0.15$ $\mathrm{mmol})$, L-alanine $(5.0 \mathrm{mmol})$, and water $(20 \mathrm{ml})$ were added to the wet cells $(0.5 \mathrm{~g})$ cultivated in PGO-medium, and the reaction mixture was incubated aerobically (reciprocating shaking at $120 \mathrm{~min}^{-1}$ ) at $25^{\circ} \mathrm{C}$; ${ }^{5}$ Conversion was measured by a GLC analysis; ${ }^{6}$ Enantiomeric excess (e.e.) and configuration $(R / S)$ were determined by GLC analyses with optically active capillary columns.

esters was not observed with the addition of L-alanine, except for the reduction of ethyl 2-oxobutanoate (1b).

The reduction of $\alpha$-keto esters by the G. lucidum strain exhibited the same tendency as the $P$. salmoneostramineus $\mathrm{H} 7$ strain. The PGO-cultivated G. lucidum reduced the substrate to the corresponding hydroxy esters with high conversion ratios (2a-d, conversion $>99 \%$ ) compared to those of the PDB-cultivated G. lucidum (Table 4). Moreover, the reduction of substrates 1a-d by the PGO-cultivated G. lucidum in the water was accelerated (from $48 \mathrm{~h}$ to $12 \mathrm{~h}$ ). Furthermore, the introduction of L-alanine to the reaction mixture in water for substrates 1a-f produced the corresponding alcohols with high conversion ratios $(>99 \%)$. In particular, substrates 1a-c were reduced to $\alpha$-hydroxy esters $\mathbf{2 a - c}$ in excellent e.e. $(>99 \%$ e.e. $(R))$.

The PDB-cultivated $F$. velutipes reduced the substrates to the corresponding hydroxy esters with high conversion ratios $(>99 \%)$ compared with those reduced by PGOcultivated $F$. velutipes, as shown in Table 5 . In the reduction catalyzed by $F$. velutipes, there was no the improvement in the products' stereoselectivity with the addition of L-alanine.

Thus, 6 aliphatic $\alpha$-keto esters were converted to the corresponding $\alpha$-hydroxy esters by 4 basidyomycete strains. In terms of the reduction conversion rates and the enantioselectivity of the products, these results suggest that the $P$. salmoneostramineus $\mathrm{H} 7$ strain and G. lucidum are 
potential biocatalysts for the stereoselective reduction of keto esters to obtain chiral hydroxy esters.

\section{Conclusion}

In order to search for new applications of mushrooms, the ability of 19 edible mushrooms to act as biocatalysts were examined. These 19 strains were cultivated in the PDB liquid medium, but cell growth was slow. Therefore, we designed 3 modified culture media (PG, O, and PGO medium), and found that the PGO medium, which contains pectin, arabic gum, and olive oil, was suitable for the liquid cultivation of basidiomycete. In particular, over $10 \mathrm{~g}$ of wet cells were harvested after a short period of time when 4 basidiomycete strains were cultivated in PGO medium (P. salmoneostramineus H7, salmoneostramineus $\mathrm{H} 13, G$. lucidum, and $F$. velutipes). The reduction of $\alpha$-keto esters using each of these 4 strains was tested. We found that these strains exhibited reducing activity toward 6 aliphatic $\alpha$-keto esters. Furthermore, the stereospecific reductions of some $\alpha$-keto esters to the corresponding $(R)$-alcohols, using $P$. salmoneostramineus $\mathrm{H} 7$ or $G$. lucidum in the presence of L-alanine, was accomplished with excellent e.e. (>99\%). As mentioned above, we found that some edible mushroom could be used as biocatalysts for stereoselective reductions of $\alpha$ keto esters, a similar finding to reports that studied bakers' yeast.

\section{Acknowledgements}

This study was partially supported by the Ministry of Education, Culture, Sports, Science and Technology of Japan through a Financial Assistance Program for Social Collaborative Research (2006-2010).

\section{REFERENCES}

[1] A. T. Borchers, J. S. Stern, R. M. Hackman, C. L. Keen and M. E. Gershwin, "Mushrooms, Tumors, and Immunity," Proceedings of the Society for Experimental Biology and Medicine, Vol. 221, No. 4, 1999, pp. 281-293. doi:10.1046/j.1525-1373.1999.d01-86.x

[2] A. T. Borchers, C. L. Keen and M. E. Gershwin, "Mushrooms, Tumors, and Immunity: An Update," Experimental Biology and Medicine, Vol. 229, No. 5, 2004, pp. 393406.

[3] A. T. Borchers, A. Krishnamurthy, C. L. Keen, F. J. Meyers and M. E. Gershwin, "The Immunobiology of Mushrooms," Experimental Biology and Medicine, Vol. 233, No. 3, 2008, pp. 259-276. doi:10.3181/0708-MR-227

[4] R. Kondo and I. Kamei, "Biodegradation of Dioxins and PCBs by Mushroom Fungi," BioIndustry, Vol. 23, No. 12, 2006, pp. 68-76.

[5] A. S. Purnomo, T. Mori, I. Kamei, T. Nishii and R. Kon- do, "Application of Mushroom Waste Medium from Pleurotus ostreatus for Bioremediation of DDT-Contaminated Soil," International Biodeterioration and Biodegradation, Vol. 64, No. 5, 2010, pp. 397-402.

[6] V. A. Edalli and C. M. Kamanavalli, "Removal of Phenolic Compounds by Mushroom Polyphenol Oxidase from Pleurotus Species," Ecoscan, Vol. 4, No. 1, 2010, pp. 8992.

[7] T. Eggen, "Application of Fungal Substrate from Commercial Mushroom Production-Pleurotus ostreatus-for Bioremediation of Creosote Contaminated Soil," International Biodeterioration and Biodegradation, Vol. 44, No. 2-3, 1999, pp. 117-126.

doi:10.1016/S0964-8305(99)00073-6

[8] K. Ishihara, K. Iwai, H. Yamaguchi, N. Nakajima, K. Nakamura and T. Ohshima, "Stereoselective Reduction of $\alpha$ and $\beta$-Keto Esters with Aerobic Thermophiles, Bacillus Strains," Bioscience, Biotechnology, and Biochemistry, Vol. 60, No. 11, 1996, pp. 1896-1898. doi:10.1271/bbb.60.1896

[9] K. Ishihara, M. Nishitani, H. Yamaguchi, N. Nakajima, T. Ohshima and K. Nakamura, "Preparation of Optically Active $\alpha$-Hydroxy Esters: Stereoselective Reduction of $\alpha$ Keto Esters Using Thermophilic Actinomycetes," Journal of Fermentation and Bioengineering, Vol. 84, No. 3, 1997, pp. 268-270. doi:10.1016/S0922-338X(97)82068-5

[10] K. Ishihara, H. Yamaguchi, H. Hamada, N. Nakajima and K. Nakamura, "Stereocontrolled Reduction of $\alpha$-Keto Esters with thermophilic Actinomycete, Streptomyces thermocyaneoviolaceus IFO14271," Journal of Molecular Catalysis B: Enzymatic, Vol. 10, No. 4, 2000, pp. 429434. doi:10.1016/S1381-1177(99)00115-0

[11] K. Ishihara, H. Yamaguchi, N. Adachi, H. Hamada and N. Nakajima, "Stereocontrolled Reduction of $\alpha$ - and $\beta$-Keto Esters with Micro Green Algae, Chlorella Strains," Bioscience, Biotechnology, and Biochemistry, Vol. 64, No. 10, 2000, pp. 2099-2103. doi:10.1271/bbb.64.2099

[12] K. Ishihara, N. Nakajima, H. Yamaguchi, H. Hamada and Y. Uchimura, "Stereoselective Reduction of Keto Esters with Marine Micro Algae," Journal of Molecular Catalysis B: Enzymatic, Vol. 15, No. 1-3, 2001, pp. 101-104. doi:10.1016/S1381-1177(00)00247-2

[13] K. Ishihara, H. Yamaguchi and N. Nakajima, "Stereoselective Reduction of Keto Esters: Thermophilic Bacteria and Microalgae as New Biocatalysts," Journal of Molecular Catalysis B: Enzymatic, Vol. 23, No. 2-6, 2003, pp. 171-189. doi:10.1016/S1381-1177(03)00081-X

[14] K. Ishihara, H. Nagai, K. Takahashi, M. Nishiyama and N. Nakajima, "Stereoselective Reduction of $\alpha$-Keto Ester and $\alpha$-Keto Amide with Marine Actinomycetes, Salinispora Strains, as Novel Biocatalysts," Biochemistry Insights, Vol. 4, 2011, pp. 29-33. doi:10.4137/BCI.S7877

[15] K. Nakamura, K. Inoue, K. Ushio, S. Oka and A. Ohno, "Stereochemical Control on Yeast Reduction of $\alpha$-Keto Esters. Reduction by Immobilized Bakers' Yeast in Hexane," Journal of Organic Chemistry, Vol. 53, No. 11, 1998, pp. 2589-2593. doi:10.1021/jo00246a035 